sciendo
Management Consulting Journal

Volume 5.1 | January 2022

DOI: $10.2478 / \mathrm{mcj}-2022-0003$

ISSN: $2631-987 X$

\title{
Practice in Advanced, Emerging Economies, and Azerbaijan
}

\author{
Samir Novruzov
}

\section{Abstract}

The purpose of this paper is to clarify the essence of the Management Consulting phenomenon, as it applies to the Azerbaijan Republic and other regions.

The first part focuses on the historical basis of the establishment of Management Consulting as a separate profession and field, the arguments about it, and the geography of the initial spread. The second part clarifies some questionable practices in this area. The third part clarifies the level of consulting activities in Azerbaijan, consulting habits, and approach of the local community in this area, and the fundamental obstacles that make the phenomenon impossible to develop. 


\section{Introduction}

As the world develops, there will always be a need for an optimal solution, knowledge, insight, and advice from third parties to make a product better, more reliable, more practical, or more effective in the shortest time. Despite the prevailing stereotypes in the local market that make this phenomenon impossible, forming a consulting culture is inevitable. The results of surveys conducted in leading economies, including developing countries, show that with the right approach and application, Management Consulting (MC) can be helpful for the development of the Azerbaijani economy.

Due to the lack of any research, articles, or survey results of the ratio of the phenomenon in the domestic market, the local market analysis is the product of observations based on the author's personal relevant analysis, and in-depth experience. The author hopes that the relevant analysis will become a valuable and effective tool for the emergence of real MC practice and the development of the domestic market in Azerbaijan, i.e. give the initial impetus for the first-hand study of the already formed consulting culture by our local institutions and scientists.

\section{Historical Roots of Management Consulting}

The adoption of $\mathrm{MC}$ as a separate field of science has given impetus to the growth of this field. The first management consulting practice is associated with Frederick Winslow Taylor, who in 1893 opened an independent consulting practice in Philadelphia, USA (Copley \& Barkley, 1923). Since scientific management has already become a part of our lives, few know that this term is a masterpiece of its founder, Frederick W.T., a Philadelphian aristocrat who devoted his life to understanding the nature of work (Lehmann-Haupt, 1997).

Although the historical origins of consulting are dominated by those who believe that it is Taylorism, differing views including Kipping (1999) and McKenna (2006) claim that the history of this particular profession is linked to some legislative changes in the United States (Ciumara, 2014). According to this view, modern MC dates back to the 1920s and 1930s. Some authors, such as McKenna (2006) and O'Mahoney (2010) link the history of the consulting profession with the 1933 Glass-Steagall Act in the United States, which provides for an absolute separation of the activities of commercial and investment banks. According to the law, commercial banks are prohibited from engaging in any non-banking activities and consulting on management issues. This decision opened a new market for independent consulting companies (McKenna, 1995). In particular, it led to the institutionalisation of the phenomenon of Management Consulting. Since other countries have not enacted laws to separate commercial and investment banks, there has never been an institutionalisation of management consulting in countries other than the United States (McKenna, 1995).

When American management consultants began to expand into Europe in the early 1960s, they successfully sold 'know-how' to organisational managers who wanted to incorporate it into organisational structures on governance principles which J.J.ServanSchreiber called the "American Challenge" (Jean-Jacques \& Jr., 1979). In the 1970s, 
McKinsey and Company centralised a quarter of Britain's 100 largest companies (McKenna, 1995). In doing so, they have spread the seeds of American management techniques and methodologies throughout the world.

In general, $\mathrm{MC}$ organisations play a vital role in developing the private sector of the leading countries, increasing the efficiency and effectiveness of the public sector, and the demand for them is constantly growing. The reason is clear: to keep pace with the environment of rapid socio-economic development, the ever-increasing competition between businesses, the creation of a modern approach in all industries and their installation in these businesses is becoming an increasingly valuable, or invaluable, raw material. In addition to the benefits associated with the growth of $M C$, there are complications and side effects of this phenomenon's progress. The next part analyses the consulting industry from this perspective.

\section{The Shadow Side of Management Consulting}

In the activities of giant Transnational Corporations (TNCs) of the consulting industry, who have become critical players in the management of global economies in various parts of the world, various forms of deviations and complications are identified under the requirements of the specific local socio-economic environment and the interests of key market players. Many of the giant consulting companies that have become TNCs have been implicated in scandals involving corruption, monopolies, and even fraud and financial machinations. For example, McKinsey Consulting has been accused of systematic corruption and abuse with local partners in government agencies and stateowned companies. According to the court decision, the company will have to pay $\$ 43$ million in compensation to the South African government (Cotterill, 2020). According to the Tussell think tank, McKinsey has won $£ 218$ million in contracts from the UK government over the past three years. This figure is the highest share of global strategic consulting. (Financial Times, 2021).

In 2016, the Big Four employed 890,000 people in 150 countries. This figure is higher than the total of the five wealthiest companies in the world (Brooks, 2018). The Quartet currently acts as a provider of all possible professional services, from integrating ICT systems to ownership and procurement and corporate strategies. The Quartet does not even shy away from sending social messages to society. Ernst \& Young's global brand and external relations leader delivered a biblical message in 2016: "You think of the right hand of supremacy, but in fact, our alumni can be the right hand of our supremacy." (Brooks, 2018). However, while looking at their actions, it is difficult to find the "supremacy" they claim. "Spotlight on Corruption" claims that the Royal Trade Service of the United Kingdom, which buys goods and services, banned EY from participating in London-based public sector contracts and procurement for at least three years (The Economic Times, 2020).

Thus, in order not to misunderstand the complexity of the MC phenomenon and it is important not to treat this industry as a universally wholesome phenomenon. In the next part, a thorough analysis is made of the actual practice of $\mathrm{MC}$ in the local market, taking into account the specificities of the socio-economic environment of Azerbaijan. 


\section{Consulting Culture in Azerbaijan}

A culture of active consulting in the local market has not yet been formed. For this phenomenon to become a reality, it is necessary to develop appropriate approaches and social habits that ensure the development of these practices in the domestic market, a rational outlook and an adequate socio-economic and political environment. This section analyses the existing MC practice in Azerbaijan in terms of the above factors.

The tendency to seek consulting advice in our domestic market is much lower than in leading countries. Existing consulting services are primarily in the form of legal advice, which has been operating since the 1990s, and more recently, services related to taxation and accounting.

Unfortunately, one of the top priorities on most local business managers and executives' agendas is to protect their positions at all costs and for entrepreneurs to smoothly report their activities to be reviewed by the tax authorities. Meetings with the heads of companies of both groups approaching from this perspective suggest that in order to determine the economic status of any organisation and institution, it is likely to conduct a simple financial audit to determine the economic condition of any organisation or institution by submitting a monthly financial report, profit and loss statement, balance sheet, or cash flow statement.

However, this is not enough. Any organisation, institution, or business unit should be considered a single "living organism" (Novruzov, 2020). The figures provided by the financial audit of organisations are similar to those of a person's height and weight. Even if the audit is conducted straightforwardly, this in itself is not enough to fully identify organisational shortcomings. It is essential to first diagnose the disease by gradually conducting all relevant examinations and diagnostic measurements like treating a chronic disease. In addition to the relevant financial audit, it is necessary to conduct thorough step-by-step inspections, consistent assessment, and survey at the organisational level, covering the core and entire staff of the organisation in order to solve specific problems and eliminate corporate shortcomings, disruptions, and obstacles. (Novruzov, 2020). It should be natural and rational for each individual or organisation to apply for the relevant consulting service to make the most of the money spent and ask if their expectations will be met.

However, the success of the consultation proposal depends on the readiness of the manager and the organisation to implement the proposal at a proper level, quality, and timing. This is similarly exampled in the therapist-patient relations, where the main guarantee of the effectiveness of the treatment is in the patient's approach to the complex treatment scheme presented by the relevant qualified doctor and the responsibility incurred from such. In short, to properly understand the phenomenon of consulting in the domestic market, a culture of consultation must be formed at all levels of public thinking, starting with human habits. 


\section{Factors Management Consulting Needs to be Feasible (to live)}

In order for MC practices to be feasible in the local market of Azerbaijan, first of all, the share of SMEs in GDP must be substantially high. Analogically, SMEs should have significant access to the financial resources in order to afford to apply the varied growth mechanisms, methods, and tools contributing to the true development of enterprises; thus, having the capability and will to request consultancy. It is essential to take into account that while mentioning SMEs, MC firms are also included in this group range. Why is SMEs existence and growth is a paramount factor? Because any SME having a capability and intention to grow itself would obviously require and demand the method or tool contributing to achieving a goal. Consequently, SMEs that require advice ultimately would never go to the Big Four, but a small or medium-size consulting firm. The statement claimed by OECD approves that SMEs need business services such as consulting, training, accounting, legal, advertising, marketing, and IT services to improve their competitiveness (OECD, 2004).

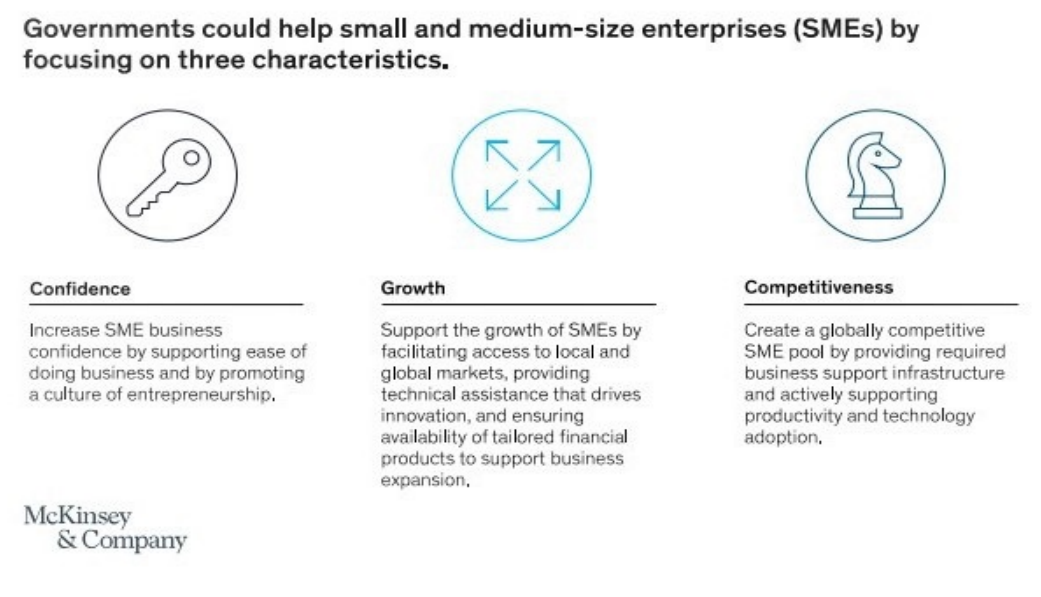

The competitiveness factor in the aforementioned statement of OECD (2004) is also an important point. In order for MC firms to get an opportunity to provide growth and optimization advice to the market, the local market environment has to be competitive and ensure fair, equal opportunities (EO). However, the complicated system prevailing in the Azerbaijan socio-economic reality and the presence of all elements of damaging practice limit the development of SMEs and, as a result, make it impossible to create a real need for consulting practices. McKinsey and Company states that any government or NGO aiming for the growth of SMEs should focus on promoting three characteristics of a healthy and well-performing SME environment: boosting the business confidence of SMEs; enabling the growth of SMEs; and increasing the competitiveness of SMEs (Albaz, Dondi, Rida, \& Schubert, 2020).

The government offers some assistance to promote SMEs, such as the Entrepreneurship Development Fund under the Ministry of Economy. However, these efforts are not sufficient to ensure the development of the critical SME sector (ADB, 
2014). In particular, it is not clear what management consulting skills are covered by the services provided by KOBIA (Small and Medium Business Development Agency, 2021), which is formally a consulting company in public administration. What is the specificity of most SMEs' appeals related to and level of management mechanisms applied? Additionally, to what extent are the agency's services unique and effective for the efficient dynamics of SMEs' development? Are the provided services and opportunities corresponding to equal opportunities? Consequently, there is no research data, survey results, or information on the impact of services provided by KOBIA on the businesses' KPIs or growth.

The majority of SMEs in Azerbaijan are concentrated in relatively low value-added activities such as vehicle trade and repair, transportation and storage, accommodation, and catering services (OECD, 2020). This trend profoundly clarifies SMEs limited access to financial resources, thus incapability for requesting $\mathrm{MC}$ services.

The existence of a monopoly and the bureaucratic dysfunction, and the love for bureaumania (described by Marie Vincent de Gournay as a disease that complicates a healthy economy (Acar \& Aupperle, 1984)) often make it impossible to grow SMEs, thus ensuring competitive local market (CLM). The Azerbaijani government acknowledges the existence of corruption practices, bribery, and nepotism in human resource management, discrimination in employment and promotion, illegal dismissals, and violations of labour rights (OECD, 2016). Meritocracy in the bureaucratic system of the state is violated by radical clientelism, cronyism, and nepotism (Bertelsmann Stiftung, 2020). These harmful tendencies in the state ultimately simultaneously manifest themselves, thus brutally corrupting the essence of the consulting phenomenon. The risk of corruption involving public procurement funds is extremely high, thus the same people and business groups engage in multiple procurements by creating different companies under different names (Aghayev, 2021). Suspicious transactions motivated by the Ministry of Labour and Social Protection (MLSP) while procuring consultancy services worth $\$ 100 \mathrm{mln}$ had been loaned from the World Bank for the Employment Support Project (Azpolitika.info, 2021). Awarded consulting companies of procurement tenders claimed to be founded by the brother-in-law of deputy minister of MLSP of Azerbaijan Republic (Azinform.az, 2021). Unfortunately, the abundance of factors deteriorating the national economy prevails, i.e. can't be listed right away.

Stereotypes dictated by the local environment, such as the fact that the consultancy meetings are often mediated by relations playing the jury's role, do not consider the arrangement and payment of the first consultation to be a proper step in the long term. This trend has become a dogma and a regular occurrence. It is due to the lack of a culture of consulting in the local market and the lack of consulting mindset.

It is gratifying that there are those among the managers of many business entities who accept the existence of relevant shortcomings and gaps in their work. A small number of entrepreneurs turn to independent consultants to find the optimal way to the goals that ensure the development and growth of their business. The vast majority of managers who turn to consultants prefer to get the necessary advice and strategic steps identified at the first meeting, free of charge. One of the main reasons for the widespread use of such abuses is that independent consultants view each meeting as a potential project and hope for an agreement between the parties. On the other hand, there are the 
factors like unhealthy intent and unprofessionalism stemming from a potential customer trying "to grow his business for a cup of tea". This approach is a sign of the community's inclination to the informal agreements promoting shadow economy.

In addition, the existence of negative trends in almost all areas that form the core of the national economy make it impossible to form an authentic consulting culture. According to a study by the Association of Chartered Certified Accountants (ACCA), the shadow economy in Azerbaijan accounted for 67\% and 66\% of GDP in 2016 and 2017, respectively (Bertelsmann Stiftung, 2020). This indicates that the shadow economy of Azerbaijan outstrips those in India (16.55\% of GDP), China (10.17\%), Bulgaria (29.85 $\%)$, Ukraine (45.96 \%), and Nigeria (47.7\%) (bne IntelliNews, 2017).

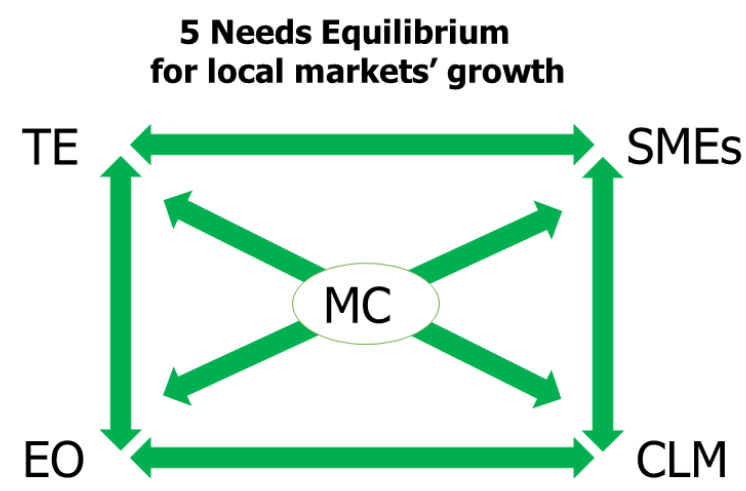

Transparent Economy - Small and Medium Sized Enterprises - Equal Opportunities - Competitive Local Market Management Consulting

Source: Management Consulting Journal : "5 Needs Equilibrium” pattern is developed by Samir Novruz

Weaknesses in the education system and labour market policy make it difficult to develop the modern skills and knowledge required for a non-oil economy to be competitive and loyal to innovation (ADB, 2014). The fertile ground for the development of shadow relations is created only by a system that can significantly interfere in the processes of production, distribution, exchange and consumption, i.e. it interferes with the objective laws of economic development (Goldenberg, 1991). Based on the aforementioned opinions, the following pattern is revealed naturally. For MC's functionality, it has been required core interrelated factors as dynamic involvement of SMEs in GDP making, existing of Transparent Economy (TE) and CLM (Competitive Local Market), and ensuring EO (Equal Opportunities). These factors are interrelated and require one another for a dynamic life cycle significantly contributing to the growth of the national economy.

Of course, all mentioned factors and their correlations with consulting industry that are claimed in this paper for being essential tools for the growth of the local economy haven't been directly researched at this time, but best would be researched thoroughly in a separate way.

\section{Consulting Habits of the Major Players in the National Economy}


Unlike small and medium-sized businesses in the domestic market, the approaches and attitudes of prominent players to consulting, on the contrary, can be considered dense and dynamic. SOCAR and SOFAZ, which are the backbone of the Azerbaijani economy, and prominent holdings (e.g. Pasha Holding) and banks (e.g. Pasha Bank), which are major players in the market, prefer to use the services of Big Four audit and consulting companies to emphasise the idea of transparent accountability, by putting their assets into an IPO (Reuters, 2019) in order to be monetised, as well as to gain prestige and a credible global rating. This process requires our local companies to pay substantially high figures for consulting and auditing services. Information about this is usually kept secret from the public under the guise of trade secrets. Of course, the best in the world would prefer to work with the best, even if we talked about fantastic numbers. For example, Baron Frank Field, former chairman of the UK Labor and Pension Committee, shared his opinion: "As elite executives, PwC will require $£ 50$ million for six months under a contract to print money without competition" (Mckenna, 2020).

EY's official report "Guide to doing business in Azerbaijan" (EY, 2014), makes it clear that EY covers the most critical projects in the geopolitical and economic scene of Azerbaijan like BTC (Baku-Tbilisi-Ceyhan), SCP (The South Caucasus Pipeline), AGSC (SOCAR, 2021), as well as partnership agreements with TNCs such as BP, Statoil, Lukoil. It is also known that EY supplies financial, tax, and legal consulting services, and audits quite big local market players like Garadagh Cement, Bakcell, Azerfon, Azpetrol, Azertrans, Crescent Beach, and Azeurotel. PwC, SOCAR's official consulting partner (PwC, 2014), has been operating in Azerbaijan since 1995. The current situation clarifies that consulting practices in all strategic projects that can be considered profitable in the Azerbaijani economy are necessary and unavoidable by the Quartet. The relevant services are continuously distributed among the Big Four.

One of the biggest Big Four permanent partners in Azerbaijan, SOFAZ, is ranked 4th among sixty sovereign wealth funds in the fourth edition of the Sovereign Wealth Fund's (SWF) Transparency and Accountability, published by the Peterson Institute for International Economics in 2016 (IFSWF, 2021). However, when examining the effectiveness of SOFAZ, it is determined that the fund has essentially deviated from its direction and purpose. Whilst looking at the activities of SOFAZ, it is clear that since 2012, it has spent most of its income, ignoring intergenerational capital. For comparison, in 2017, SOFAZ's return on investment was $8.9 \%$ of annual income. Meanwhile, SOFAZ's expenses amounted to $90.76 \%$ of annual revenue, which violated the $25 \%$ savings rule (Muxtarov, 2019).

Naturally, the following presumptions are raised: Either the consultations of the Big Four have failures in the principles of effectiveness, or the strengthening of the national economy is not the subject of these consultations. Alternatively, their proposals, steps, and solutions are not followed at all. 


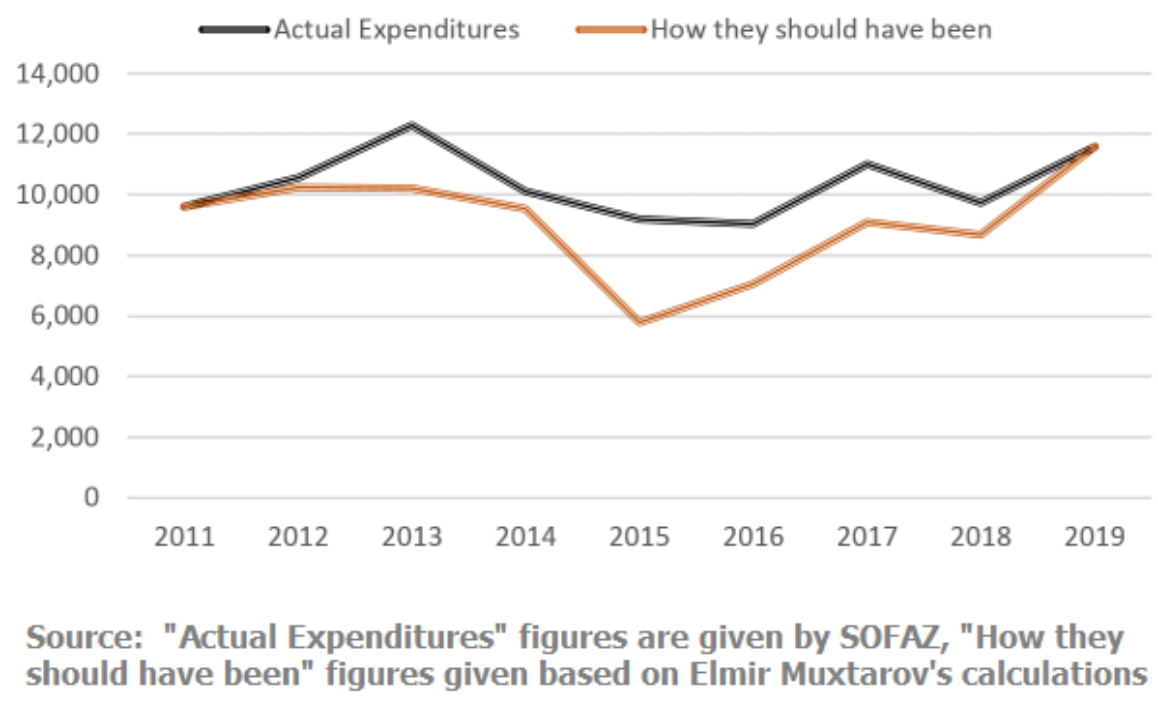

When approached by local staff development, Big Four and their big partners (TNCs) also serve as a springboard for progress at the individual level and future career development. The typical indicators of these corporations are the ability and skills of leading economies to create systematic development dynamics, corporate culture, and effective team environments, and establish employee value schemes - in short, consistently mobilising KPIs to achieve the set goals.

Therefore, it is not surprising that the heads of many local institutions and organisations associated with such corporations tend to favouritism, making behind-the-scenes deals involving hiring their children, relatives, and potential staff for "being roasted" in a developed environment and achieving career development. This trend is also typical of leading economies. "Of course, there are young people, who have an additional advantage over ordinary Joes and Janes, or more specifically, candidates who have a relationship with their Big Four partners. Maybe they are relatives, friends or just servants in their country clubs." (Newquist, 2012).

At present, the deep-rooted harmful practices, violations and abuses in the national economy make it impossible to create a real need for consulting practices. In this section, we have been able to analyse the reasons for the non-existence of the MC phenomenon in Azerbaijan and the decades-old obstacles that make it impossible to use it as a fundamental tool contributing to the development of the national economy.

\section{Conclusion}

The transformation of the consulting organisations created a century ago into the largest TNC of our time is underpinned by the fundamental strategic steps and perseverance of vision, effort, and diligence, and most importantly, the habit of competition. Of course, trying to outdo competitors and maintain leadership does not always happen without 
side effects. Therefore, the involvement of consulting giants in the management of global economies in severe violations of the law, such as cartel agreements, systematic corruption, financial machinations, and purposeful application of favouritism and nepotism, following the requirements of the actual socio-economic environment in different geographies should not raise any doubt.

The current prevalence of destructive practices, such as corruption and monopolies, cartel-type deals, artificial red tape, favouritism, and other abuses in the Azerbaijan economy, makes it impossible to create a real need for consulting practices. In order for consulting practices to be required in the local market of Azerbaijan, first of all, at least, the share of SMEs in GDP should significantly increase, TE, CLM and EO should be insured. However, the prevailing unhealthy system of the national economy and all the trends of negative practices limit the development of " 5 Needs Equilibrium" factors, thus undermining to contributing the growth of the national economy.

SOCAR, SOFAZ and other key market players prefer to use the services of the most expensive MC firms like the Big Four, to emphasise the idea of transparent accountability and gain a prestigious global rating. However, to what extent do luxury contracts play a role in the development of relevant strategic institutions? Why the Big Four are preferred in implementing the most strategic and profitable projects, and most importantly, the extent to which these choices, repeated over decades, have affected the development of the national economy remains a question.

There is ample evidence that MC practices play an essential role in developing local economies and businesses in advanced and emerging markets. The detailed research results confirm that the trend towards consulting practice is expedient, functional, and effective. It is hoped that the relevant analysis will lead to the emergence of an actual, effective MC practice in Azerbaijan, that this phenomenon will become a healthy, effective tool for the natural development of the national economy and a healthy contribution to the proper study of consulting culture. 


\section{References}

Acar, W. \& Aupperle, K.E. (1984). Bureaucracy as Organizational Pathology. Systems Research Vol. I. No 3. pp 157-166.

Bertelsmann Stiftung. (2020). BTI 2020 Country Report - Azerbaijan. Gütersloh: Bertelsmann Stiftung.

Abdulaziz Albaz, Marco Dondi, Tarek Rida, and Jorg Schubert.(2020). Unlocking growth in small and medium-sized enterprises. McKinsey and Company.

https://www.mckinsey.com/industries/public-and-social-sector/our-insights/unlockinggrowth-in-small-and-medium-size-enterprises

Aghayev, R. (2021). Public Procurement in Azerbaijan: Limits on Transparency and Public Oversight. Baku Research Institute. https://bakuresearchinstitute.org/en/publicprocurement-in-azerbaijan-limits-on-transparency-and-public-oversight/

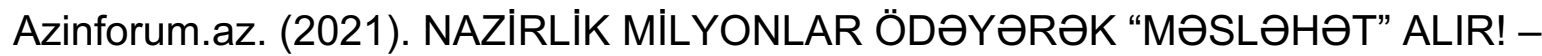
Yeznə-qayın işbirliyi dövlətə neçəyə başa gəlir? https://azinforum.az/manset/nazirlikmilyonlar-od\%C9\%99y\%C9\%99r\%C9\%99k-m\%C9\%99sl\%C9\%99h\%C9\%99t-aliryezn\%C9\%99-qayin-isbirliyi-dovl\%C9\%99t\%C9\%99-nec\%C9\%99y\%C9\%99-basag\%C9\%99lir/

Azpolitika.info. (2021). 100 MILYONLUQ KREDITI MILYON-MILYON “əRITMOK”... Omək Nazirliyindəki tender korrupsiyasının yeni detalları.

https://azpolitika.info/?p=653219

bne IntelliNews. (2017). bne IntelliNews: https://www.intellinews.com/azerbaijan-sshadow-economy-a-staggering-66-of-gdp-124699/

Brooks, R. (2018). The financial scandal no one is talking about. The Guardian. https://www.theguardian.com/news/2018/may/29/the-financial-scandal-no-one-istalking-about-big-four-accountancy-firms

Bruhn, M., Karlan, D., \& Schoar, A. (2017). The Impact of Consulting Services on Small and Medium Enterprises: Evidence from a Randomised Trial in Mexico. Policy Research Working Paper; No. 6508. World Bank

Byrne, J. A. (2016). MBA Envy? Not When You Know The Crazy Hours MBAs Work. Poets \& Quants: https://poetsandquants.com/2016/06/17/mba-envy-not-know-hardworkl

Ciumara, T. (2014). Procedia Economics and Finance 8. Elsevier BV, 175-181. Consultancy.uk. (2017). The 10 largest consulting firms in the world. https://www.consultancy.uk/news/14018/the-10-largest-consulting-firms-in-the-world 
Consultancy.uk. (2019). 8 out of 10 UK companies hire consultants, and are satisfied. https://www.consultancy.uk/news/19841/8-out-of-10-uk-companies-hire-consultantsand-are-satisfied

Copley, \& Barkley, F. (1923). Frederick W. Taylor, father of scientific management. New York: Harper and Brothers.

Cotterill, J. (2020). McKinsey to repay more than $\$ 40 \mathrm{~m}$ over South African scandal. Financial Times.

Duflo \& Karlan (2012). Can Management Consulting Help Small Firms Grow? Stanford Social Innovation Review.

https://ssir.org/articles/entry/can_management_consulting_help_small_firms_grow

EY. (2014). Guide to doing business in Azerbaijan. Ernst \& Young Holdings (CIS) BV.

Financial Times. (2021). McKinsey: after the fall. Financial Times, 2-3.

https://www.ft.com/content/81ff3fef-de1a-469d-ad91-c3f82a4510fd

Goldenberg, I. (1991). Классовая сущность "симбиоза. Социологические исследования, 39-49.

Jean-Jacques, S.-S., \& Jr., A. M. (1979). The American Challenge. Holiday House.

Kipping, M. (1999). American Management Consulting Companies in Western Europe, 1920 to 1990: Products, Reputation, and Relationships. Business History Review, 73(2), 199-220.

Markovits, D. (2020). How McKinsey Destroyed the Middle Class.

https://www.theatlantic.com/ideas/archive/2020/02/how-mckinsey-destroyed-middleclass $/ 605878 /$

McKenna, C. D. (1995). The Origins of Modern Management Consulting. Business and Economic History, 24(1), 51-58.

McKenna, C. D. (2006). The world's newest profession: management consulting in the twentieth century. Cambridge University Press.

Mckenna, F. (2020). Should companies use Big 4 audit firms to implement enterprise financial software? The Dig: https://thedig.substack.com/p/should-companies-use-big-4audit

Muxtarov, E. (2019). State Oil Fund of Azerbaijan - A Disoriented SWF. https://economir.com/2019/03/01/state-oil-fund-of-azerbaijan-a-disoriented-swf/

Newquist, C. (2012). Reminder to PwC Partners: The Firm Won't Be Considering Your Deadbeat Relatives for a Job. Going Concern: https://www.goingconcern.com/reminderpwc-partners-firm-wont-be-considering-your-deadbeat-relatives-job/ 
Novruzov, S. (2020). Наши предприниматели вынуждены распылять усилия и деньги. 10. (R. Nasirov, Интервьюер) https://ru.oxu.az/economy/417978

OECD. (2004).PROMOTING SMEs FOR DEVELOPMENT. Paris: OECD Publishing.

OECD. (2016). Anti-Corruption Reforms in Azerbaijan. Paris: OECD.

OECD. (2020). SME Policy Index: Eastern Partner Countries 2020. Paris: OECD Publishing.

O'Mahoney, J. (2010). Management Consultancy. Oxford University Press, 17.

PwC. (2014). PwC Azerbaijan is the Official. SOCAR OGPC Forum, 5-6 November. Baku:

Reuters. (2019). Azerbaijan's SOCAR plans IPO of Turkish subsidiary in 2021 -official. https://www.reuters.com/article/instant-article/idINL8N2373RR

Servan-Schreiber, J-J. (1979). The American Challenge. New York: Scribner.

SMBDA. (2021) Small and Medium Business Development Agency of the Republic of Azerbaijan. https://smb.gov.az/en/nav/reports

SOCAR. (2021). SOCAR takes over the operatorship of the Azerbaijan Gas Supply Company and the South Caucasus Pipeline Company. SOCAR News Archive. https://socar.az/socar/en/news-and-media/news-archives/news-archives/id/8367

Statista. (2019). Size of the global management consulting market in 2019, by country(in billion US dollars). Statista Research Department.

https://www.statista.com/statistics/1065188/management-consulting-market-sizecountry/\#: :text=The\%20global\%20management\%20consulting\%20market,billion\%20U .S.\%20dollars\%20in\%202019.

The Economic Times. (2020). UK's Big Four auditors await shake-up as corruption probes add up. The Economic Times.

https://economictimes. indiatimes.com/news/international/business/uks-big-four-auditorsawait-shake-up-as-corruption-probes-add-up/articleshow/79490050.cms 